\title{
CLINICAL SIGNIFICANCE OF VEGF-A AND MICROVESSEL DENSITY IN DIFFUSE LARGE B-CELL LYMPHOMA AND LOW-GRADE FOLLICULAR LYMPHOMA
}

\author{
Labinot Shahini ${ }^{1}$, Slavko Gašparov ${ }^{2}$, Gordana Petruševska ${ }^{3}$, Suzana Manxhuka Kerliu ${ }^{1}$, \\ Fahredin Veselaj ${ }^{4}$, Fisnik Kurshumliu ${ }^{1}$ and Floren Kavaja ${ }^{5}$
}

${ }^{1}$ Institute of Pathology, Faculty of Medicine, University of Prishtina, Prishtina, Kosovo;

${ }^{2}$ Department of Pathology and Cytology, Merkur University Hospital, School of Medicine, University of Zagreb, Zagreb, Croatia; ${ }^{3}$ Institute of Pathology, Faculty of Medicine, Cyril and Methodius University of Skopje, Skopje, Macedonia; ${ }^{4}$ Department of Urology, University Clinical Centre of Kosovo, Prishtina, Kosovo;

${ }^{5}$ Department of Surgery, University Clinical Centre of Kosovo, Prishtina, Kosovo

SUMMARY - Angiogenesis is essential for the development, growth and progression of tumors. Although vascular endothelial growth factor (VEGF) is a well-known proangiogenic factor, its impact on lymphoma has not yet been fully clarified. The aim of this study was to evaluate VEGF-A expression and microvessel density (MVD) in aggressive lymphoma such as diffuse large B-cell lymphoma (DLBCL), in indolent lymphomas such as low-grade follicular lymphoma (FL), and in lymph node reactive follicular hyperplasia $(\mathrm{FH})$. In 80 prospective and retrospective cases $(30 \mathrm{DLBCL}, 30 \mathrm{FL}$ and $20 \mathrm{FH}), \mathrm{CD} 31$ was analyzed by immunohistochemical staining assessing density of blood vessels, as well as the total number of CD31 positive endothelial cells. The results were compared with relevant clinical data. MVD was $85 \%$ in FH, followed by $60 \%$ in DLBCL and $43 \%$ in low-grade FL. VEGF-A was significantly higher in DLBCL than in low-grade FL and FH. A statistically significant association of MVD and VEGF-A with the International Prognostic Index (IPI) was found in DLBCL. High MVD and VEGF-A expression was observed in DLBCL patients with high IPI, while there was no statistically significant association between MVD and VEGF-A with the Follicular Lymphoma International Prognostic Index in low-grade FL. Our results suggested an important relationship between angiogenesis and high-grade lymphoma.

Key words: Vascular endothelial growth factor A; Lymphoma, non-Hodgkin; Lymphoma, large B-cell, diffuse; Lymphoma, follicular; Lymph nodes; Hyperplasia

\section{Introduction}

Diffuse large B-cell lymphoma not otherwise specified (DLBCL) is the most common type of lymphoid tumor worldwide ${ }^{1,2}$, and displays striking heterogeneity at clinical, genetic, and molecular levels. DLBCL was included both in the Revised European American

Correspondence to: Floren Kavaja, MD PhD, Bulevardi i Deshmoreve NN, 10000 Prishtina, Kosovo

E-mail: fkavaja@hotmail.com

Received March 9, 2017, accepted May 9, 2017
Lymphoma (REAL) and World Health Organization (WHO) classifications aiming to describe all malignant lymphomas characterized by the large size of neoplastic cells, B-cell derivation, aggressive clinical presentation, and need for highly effective chemotherapy regimens ${ }^{3,4}$.

Follicular lymphoma (FL) is the second most common non-Hodgkin's lymphoma. This disease affects lymph nodes, and $50 \%$ of patients present with bone marrow infiltration. However, the mechanisms involved in dissemination of the disease are still unclear ${ }^{5}$. 
FL is divided into three grades. Grades 1 and 2 are considered as lymphoma of low-grade malignancy ${ }^{6}$. Angiogenesis is the formation of new capillaries by outgrowth of endothelial cells from preexisting blood vessels ${ }^{7}$.

The Vascular Endothelial Growth Factor/Vascular Endothelial Growth Factor Receptor (VEGF/ VEGFR) pathway is a key mediator of angiogenesis and VEGF-A acts as a potent tumor angiogenic factor. VEGF-A stimulates the growth of new blood vessels that provide tumors with oxygen and nutrients, which in turn determine the proliferative activity of the tumor. Expression of VEGF-A has been shown to be regulated at the transcriptional and translational levels 8 .

VEGF-A mediated angiogenesis has received considerable attention in the context of solid neoplasia, particularly with the clinical use of anti-VEGF-A antibodies and small molecule VEGFR inhibitors. More recently, the concept of tumor vascularity has been applied to hematolymphoid neoplasia, with studies quantifying microvessel density (MVD) in a variety of lymphomas ${ }^{10,11}$.

VEGF-A-mediated signaling has at least two potential roles in DLBCL, i.e. potentiation of angiogenesis, and potentiation of lymphoma cell proliferation and/or survival induced by autocrine VEGFR-mediated signaling ${ }^{10-12}$.

Given the rapidly increasing availability of a variety of pharmaceuticals aimed at the VEGF-A pathway, the role of angiogenesis and VEGF-A signaling in DLBCL may be of great interest ${ }^{10}$.

In non-Hodgkin's lymphomas, expression of angiogenic factors in cell lines ${ }^{14}$ and neoplastic tissue ${ }^{15-17}$ has been demonstrated. Although these studies suggest a role for angiogenesis in lymphomas, several questions remain unanswered. In addition, determination of MVD as a measure of the degree of angiogenesis is also one of the most examined parameters for angiogenesis in cancers $^{13}$. It is not clear whether high MVD is associated with more aggressive lymphomas.

The aim of this study was to evaluate VEGF-A expression and MVD through expression of CD31 in endothelial cells in aggressive lymphomas such as DLBCL, in indolent lymphomas such as FL, and in lymph node reactive follicular hyperplasia $(\mathrm{FH})$.

Furthermore, we analyzed the correlation of VEGF-A expression and MVD with the Internation- al Prognostic Index (IPI) in patients with DLBCL and Follicular Lymphoma International Prognostic Index (FLIPI) in patients with low-grade FL.

\section{Materials and Methods}

In our study, we evaluated VEGF-A and CD31 expression in 30 DLBCL, $30 \mathrm{FL}$ and $20 \mathrm{FH}$ cases diagnosed at the Institutes of Pathology, Faculty of Medicine, University of Prishtina and Faculty of Medicine, St. Cyril and Methodius University in Skopje.

\section{Immunohistochemistry}

The slides were deparaffinized and rehydrated using standard procedures. Microwave heating was used for antigen retrieval and slides were then IHC stained using VEGF-A (A-20, 1:150 dilution; Santa Cruz Biotechnology Inc., USA, and CD31 (Clone JC70A, RTU; DAKO, Denmark) antibodies.

Protein expression of VEGF-A observed mainly in the cytoplasm of tumor cells was scored by combining the quantity score (percentage of positive stained cells) with the staining intensity score. All slides were analyzed independently by three pathologists. The quantity score ranged from 0 to $4: 0=$ no immunoreactivity; $1=<25 \%$ cells stained; $2=26 \%-50 \%$ cells stained; $3=$ $51 \%-75 \%$ cells stained; and $4=>76 \%$ cells stained. Then, scores 1-4 were clustered into two groups: group I (scores 1 and 2) and group II (scores 3 and 4). The staining intensity was scored as: 0 (negative), 1 (weak positivity, seen at X400 magnification), 2 (moderate, seen at X100 magnification), and 3 (strong, seen at X40 magnification). The final score was obtained by multiplying the groups of quantity score and intensity, as follows: 0 = no immunoreactivity; 1 = low positivity $(1 \%-50 \%$ of cells stained and seen at X400); $2=$ moderate positivity (1\%-50\% cells stained and seen at $\mathrm{X} 40 \mathrm{x}$ or $>50 \%$ of cells stained and seen at X400); and 3 = high positivity $(51 \%-100 \%$ cells stained and seen at X40).

Microvessel counting was used for angiogenesis assessment. CD31 immunostained tumor sections were scanned at low power magnification (X100) to identify the areas with highest vascular density, so called 'hotspots'; then MVD was calculated as the mean value of CD31-positive cells and cell clusters in five hot spots per section evaluated at X200 magnification. Subse- 


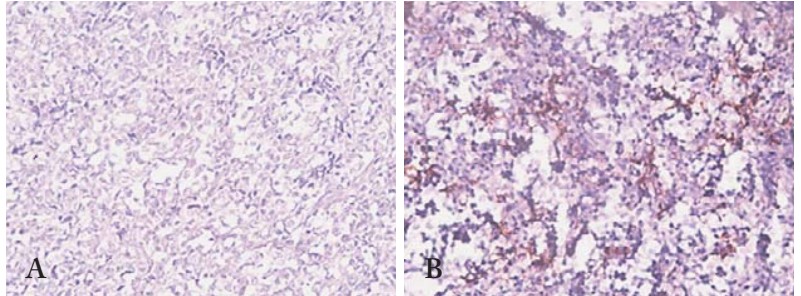

Fig. 1. VEGF-A expression: (A) no immunoreactivity; and (B) high immunoreactivity at X40 magnification.

Table 1. Number of cases per group and expression of vascular endothelial growth factor- $A$

\begin{tabular}{|l|l|l|l|l|}
\hline \multirow{2}{*}{ VEGF-A } & \multicolumn{4}{|c|}{ Score ranges } \\
\cline { 2 - 5 } & 0 & 1 & 2 & 3 \\
\hline DLBCL & 1 & 5 & 17 & 7 \\
Low-grade FL & 5 & 4 & 19 & 2 \\
FH & 5 & 5 & 10 & 0 \\
\hline
\end{tabular}

VEGF-A = vascular endothelial growth factor-A; DLBCL = diffuse large B-cell lymphoma; FL = follicular lymphoma; $\mathrm{FH}=$ follicular hyperplasia

quently, the MVD median value was used to classify each group of tumors in 'high' and 'low' MVD, by three independent observers to obtain consensus of categorization. The cut-off to categorize 'low' and 'high' MVD was a mean value of 10 blood vessels.

\section{Prognostic index}

The scoring systems, known as the IPI for DLBCL and FLIPI for FL, were used to compare results with clinical data. Three risk groups were categorized using the IPI and FLIPI scoring system: low risk, intermediate risk, and high risk ${ }^{18,19}$.

\section{Statistical analysis}

Univariate analysis was performed to assess the percentage distribution and other main characteristics of single variables used in testing the hypotheses. The $\chi^{2}$-test was used to test differences and bivariate analysis to test correlation between categorical variables. All hypotheses were tested at the 0.05 level of significance.

\section{Results}

Expression of VEGF-A in DLBCL was scored as follows: no immunoreactivity, 1 (3\%) case; low positiv-

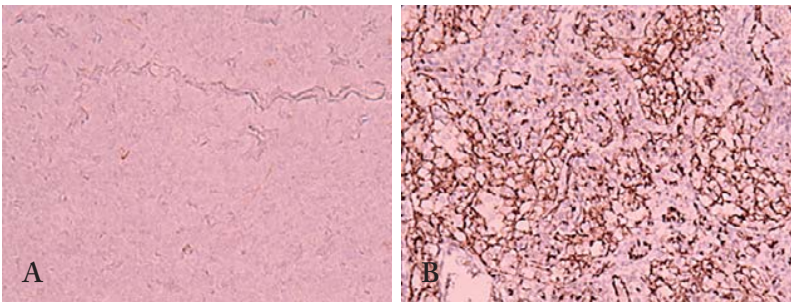

Fig. 2. CD31 staining: (A) low microvessel density; and (B) high microvessel density at X40 magnification.

Table 2. Number of cases per group and expression of microvessel density

\begin{tabular}{|l|l|l|}
\hline \multirow{2}{*}{} & \multicolumn{2}{|c|}{ MVD } \\
\cline { 2 - 3 } & Low & High \\
\hline FL & 17 & 13 \\
DLBCL & 12 & 18 \\
FH & 4 & 16 \\
\hline
\end{tabular}

$\chi^{2}=6.688, \mathrm{DF}=2, \mathrm{p}$-value 0.035

MVD = microvessel density; DLBCL = diffuse large B-cell lymphoma; $\mathrm{FL}$ = follicular lymphoma; $\mathrm{FH}=$ follicular hyperplasia

ity, 5 (17\%) cases; moderate positivity 17 (57\%) cases; and high positivity, 7 (23\%) cases (Fig. 1). However, in FL, VEGF-A expression was scored as follows: no immunoreactivity, 5 (17\%) cases; low positivity, 4 (13\%) cases; moderate positivity, 19 (63\%) cases; and high positivity, 2 cases (7\%). Lastly, in FH, 5 (25\%) cases showed low positivity and $15(50 \%)$ cases showed moderate positivity, while no cases showed high positivity (Table 1).

Positive staining for CD31 was detectable in the membrane of endothelial cells in the stroma. Of 30 DLBCL cases, 18 (60\%) showed high MVD and 12 (40\%) showed low MVD, whereas in FL 13 (43\%) cases showed high MVD and 17 (57\%) cases showed low MVD. Control group (FH) was found to have a very high expression of MVD, as 16 (80\%) cases showed high MVD and only 4 (20\%) cases showed low MVD (Fig. 2). The p-values obtained by the $\chi^{2}-$ test yielded statistically significant differences between the two groups of MVD $\left(\chi^{2}=6.688, d f=2, p=0.035\right)$ (Table 2).

Expression of VEGF-A was compared for the relationship with clinical data, i.e. prognostic index (IPI for DLBCL and FLIPI for FL). One DLBCL case without staining also had low IPI, 5 of 7 cases with high VEGF-A immunoreactivity had high IPI, an- 
Table 3. Correlation between International Prognostic Index in DLBCL and expression of CD31

\begin{tabular}{|l|l|l|l|}
\hline Variable & \multicolumn{3}{|c|}{ IPI } \\
\hline CD31 & Low & Intermediate & High \\
\hline Low & 8 & 3 & 1 \\
High & 0 & 13 & 5 \\
\hline
\end{tabular}

$\chi^{2}=16.372, \mathrm{DF}=2$, p-value 0.000 , Spearman correlation $=0.633$ DLBCL = diffuse large B-cell lymphoma; IPI = International Prognostic Index

Table 4. Correlation between International Prognostic Index in DLBCL and VEGF- $A$

\begin{tabular}{|l|l|l|l|}
\hline & \multicolumn{3}{|c|}{ IPI } \\
\hline VEGF-A & Low & Intermediate & High \\
\hline 0 & 1 & 0 & 0 \\
1 & 4 & 1 & 0 \\
2 & 4 & 12 & 3 \\
3 & 0 & 2 & 5 \\
\hline
\end{tabular}

DLBCL = diffuse large B-cell lymphoma; IPI = International Prognostic Index; VEGF-A = vascular endothelial growth factorA; study results showed highly statistically significant correlation between VEGF-A and IPI in DLBCL

other 2 cases had intermediate IPI, and no case with high immunoreactivity had high IPI (Table 3). However, 4 out of 5 FL cases with no VEGF-A immunoreactivity showed low FLIPI, and 1 case had intermediate FLIPI. Of $2 \mathrm{FL}$ cases with high expression of VEGF-A, 1 case had high and intermedicate FLIPI each.

Expression of MVD was also compared for the relationship with clinical data, i.e. prognostic index (IPI for DLBCL and FLIPI for FL). Out of 17 cases of FL with low MVD, 8 showed low, 5 intermediate and 4 high FLIPI. Four of 13 cases with high MVD showed low FLIPI, 7 intermediate FLIPI, and only 2 showed high FLIPI. Based on the test performed, there were no statistically significant differences between MVD and FLIPI $\left(\chi^{2}=1.833, \mathrm{df}=2, \mathrm{p}=0.4\right)$.

In DLBCL, different results were noted. Eight of 12 cases with low MVD showed low IPI, 3 cases intermediate, and only 1 case high IPI. No case with high MVD was in the category of low IPI, however, 13 cases were in the intermediate and 5 in the high IPI category. Study results showed highly statistically significant correlation between MVD and IPI in DLB-
CL $\left(\chi^{2}=16.372, \mathrm{df}=2, \mathrm{p}^{-}=0.000\right.$, Spearman correlation $=0.633)($ Table 4).

\section{Discussion}

Angiogenesis is a multistep process playing a crucial role in the progression and metastasis of various tumors, including those of visceral organs and hematolymphoid malignancies ${ }^{20}$. Tumor angiogenesis has been well documented both in experimental and clinical studies, and the degree of angiogenesis was closely associated with tumor progression and shorter patient survival in many types of cancer ${ }^{21,22}$. Non-Hodgkin's lymphomas are a diverse group of lymphoproliferative neoplasms with a variable clinical behavior and prognosis. Currently, lymphomas are classified on the basis of morphology, immunology, genetic, and clinical features. The clinical stage of the lymphoma is the most important prognostic factor, apart from the histologic grade (indolent versus aggressive) ${ }^{20}$.

Microvessel density measures lymphoma neovascularity generated in response to tumor cells, proangiogenic stromal cells, and infiltrating benign T/B lymphocytes and myeloid cells within the tumor microenvironment. Therefore, MVDs vary greatly among different studies due to the heterogeneity of lymphoma stroma, the range of cell surface markers used for staining, and differences in scoring methodology. The clinical predictive value of MVD with respect to underlying lymphoma subtypes remains unclear ${ }^{23}$.

In general, MVD scores trend highest in aggressive subtypes of lymphoma, compared with lower ones in indolent lymphoma. Gratzinger et al. report that average MVDs did correlate with the intensity of VEGF staining in a statistically significant manner ${ }^{24}$. In another study, increasing MVD was found to be a poor prognostic indicator for overall but not progressionfree survival, and was independent of the IPI ${ }^{25}$.

Koster et al. ${ }^{11}$ found that in FL, high MVD as a variable of increased tumor vascularization was associated with a significantly more favorable outcome in terms of both progression-free and overall survival ${ }^{26}$. Positive association between MVD and patient outcome is in contrast with the notion that in hematologic malignancies, as well as in solid tumors the increase of angiogenesis-associated variables is related to adverse prognosis ${ }^{15,22,28}$. Aggarwal et al..$^{20}$ found higher MVD in aggressive lymphoma such as peripheral T- 
cell lymphoma and DLBCL, and low MVD in lowgrade lymphomas ${ }^{2}$.

In our study, VEGF-A and CD31 staining were evaluated as markers of tumor vascularity in lymph nodes, showing significant difference in terms of MVD between high-grade lymphoma (DLBCL), which demonstrated high MVD, and low-grade FL, which showed low MVD.

Ganjo et al..$^{29,30}$ report that antiangiogenic drugs have modest clinical activity in lymphomas as a single agent. Our results may suggest that antiangiogenic therapy could be active only in high-grade lymphomas expressing stronger VEGF.

\section{Conclusion}

Neoangiogenesis has been increasingly recognized to play potentially important pathogenic roles in lymphomagenesis. We can conclude that our results support the hypothesis that there is important relationship between angiogenesis and high-grade lymphoma. Also, there is significant correlation with clinical data.

\section{Acknowledgment}

Special thanks to Iliriana Miftari for helping us with statistical analysis.

\section{References}

1. Abramson J.S, Shipp M.A. Advances in the biology and therapy of diffuse large B-cell lymphoma: moving toward a molecularly targeted approach. Blood. 2005 Aug 15;106(4):1164-74. doi: 10.1182/blood-2005-02-0687.

2. Cardesa-Salzmann TM, Colomo L, Gutierrez G, Chan WC, Weisenburger D, Climent F, et al. High microvessel density determines a poor outcome in patients with diffuse large B-cell lymphoma treated with rituximab plus chemotherapy. Haematologica. 2011 Jul;96(7):996-1001. doi: 10.3324/haematol.2010.037408.

3. Pileri SA, Dirnhofer S, Went P, Ascani S, Sabattini E, Marafioti T, et al. Diffuse large B-cell lymphoma: one or more entities? Present controversies and possible tools for its subclassification. Histopathology. 2002 Dec;41(6):482-509. doi: 10.1046/j.1365-2559.2002.01538.x.

4. Kumar S, Fonseca R, Dispenzieri A, Lacy MQ, Lust JA, Witzig TE, et al. Bone marrow angiogenesis in multiple myeloma: effect of therapy. Br J Haematol. 2002 Dec;119(3):665-71. doi: 10.1046/j.1365-2141.2002.03871.x.

5. Fruchon S, Kheirallah S, Al Saati T, Ysebaert L, Laurent C, Leseux L, et al. Involvement of the Syk-mTOR pathway in follicular lymphoma cell invasion and angiogenesis. Leukemia. 2012 Apr;26(4):795-805. doi: 10.1038/leu.2011.248.

6. WHO Classification of Tumors of Haematopoietic and Lymphoid Tissues. Lyon, 2008; p 220-33.

7. Folkman J. Anti-angiogenesis: new concept for therapy of solid tumors. Ann Surg. 1972 Mar;175(3):509-16.

8. Geng L, Chaudhuri A, Talmon G, Wisecarver JL, Wang J. TGF-beta suppresses VEGFA-mediated angiogenesis in colon cancer metastasis. PloS One. 2013;8(3):e59918. doi: 10.1371/journal.pone.0059918.

9. Hoper MM, Voelkel NF, Bates TO, Allard JD, Horan M, Shepherd D, et al. Prostaglandins induce vascular endothelial growth factor in a human monocytic cell line and rat lungs via cAMP. Am J Respir Cell Mol Biol. 1997 Dec;17(6):748-56. doi: 10.1165/ajrcmb.17.6.2888.

10. Gratzinger D, Zhao S, Tibshirani RJ, Hsi ED, Hans CP, Pohlman B, et al. Prognostic significance of VEGF, VEGF receptors, and microvessel density in diffuse large B cell lymphoma treated with anthracycline-based chemotherapy. Lab Invest. 2008 Jan; 88(1):38-47.

doi: 10.1038/labinvest.3700697.

11. Koster A, Raemaekers JM. Angiogenesis in malignant lymphoma. Curr Opin Oncol. 2005 Nov;17(6):611-6.

12. Podar K, Anderson KC. The pathophysiologic role of VEGF in hematologic malignancies: therapeutic implications. Blood. 2005 Feb 15;105(4):1383-95. doi: 10.1182/blood-2004-07-2909.

13. Mancilla JR, Stanley RJ, Blath RA. Papillary renal cell carcinoma: a clinical, radiologic, and pathologic study of 34 cases. Cancer. 1976 Dec;38(6):2469-80. doi: 10.1002/1097-0142(197612)38:6<2469.

14. Bellamy WT, Richter L, Frutiger Y, Grogan TM. Expression of vascular endothelial growth factor and its receptor in hematopoietic malignancies. Cancer Res. 1999 Feb 1;59(3):728-33.

15. Doussis-Anagnostopoulou IA, Remadi S, Turley H, Gindre P, Comley M, Borisch B, et al. Platelet-derived endothelial cell growth factor/thymidine phosphorylase immunohistochemical expression in lymphoid tissue and lymphoid malignancies. Hum Pathol. 1997 Oct;28(10):1146-51.

16. Foss HD, Araujo I, Demel G, Klotzbach H, Hummel M, Stein H. Expression of vascular endothelial growth factor in lymphomas and Castleman's disease. J Pathol. 1997 Sep;183(1): 44-50. doi: 10.1002/(SICI)1096-9896(1997)183:1<44::AIDPATH1103>3.0.CO:2-I.

17. Turley H, Scott PA, Watts VM, Bicknell R, Harris AL, Gatter KC. Expression of VEGF in routinely fixed material using a new monoclonal antibody VG1. J Pathol. 1998 Nov;186(3): 313-8. doi: 10.1002/(SICI)1096-9896(1998110)186:3<313:: AID-PATH188>3.0.CO:2-x.

18. Perea G, Altes A, Montola S, Lopez-Guillermo A, DomingoDomenech E, Fernandez-Sevilla A, et al. Prognostic indexes in 
follicular lymphoma: a comparison of different prognostic systems. Ann Oncol. 2005 Sep;16(9):1508-13.

Doi: 10.1093/annonc/mdi269.

19. Ziepert M, Hasenclever D, Kuhnt E, Glass B, Schmitz N, Pfreundschuh M, et al. Standard International Prognostic Index remains a valid predictor of outcome for patients with aggressive CD20+ B-cell lymphoma in the rituximab era. J Clin Oncol. 2010 May 10;28(14):2373-80. doi: 10.1200/JCO.2009.26.2493.

20. Aggarwal D, Srivastava G, Gupta R, Pant L, Krishan G, Singh $\mathrm{S}$. Angiogenesis in non-Hodgkin's lymphoma: an intercategory comparison of microvessel density. ISRN Hematol. 2012; 2012:943089. doi: 10.5402/2012/943089.

21. Folkman J. The role of angiogenesis in tumor growth. Semin Cancer Biol. 1992 Apr;3(2):65-71.

22. Weidner N. Intratumor microvessel density as a prognostic factor in cancer. Am J Pathol. 1995 Jul;147(1):9-19.

23. Mazur G, Wrobel T, Dziegiel P, Jelen M, Kuliczkowski K, Zabel M. Angiogenesis measured by expression of CD34 antigen in lymph nodes of patients with non-Hodgkin's lymphoma. Folia Histochem Cytobiol. 2004;42(4):241-3.

24. Gratzinger D, Zhao S, Marinelli RJ, Kapp AV, Tibshirani RJ, Hammer AS, et al. Microvessel density and expression of vascular endothelial growth factor and its receptors in diffuse large B-cell lymphoma subtypes. Am J Pathol. 2007 Apr;170(4): 1362-9. doi: 10.2353/ajpath.2007.060901.
25. Nico B, Benagiano V, Mangieri D, Maruotti N, Vacca A, Ribatii D. Evaluation of microvessel density in tumors: pro et contra. Histol Histopathol. 2008 May;23(5):601-7. doi: $14670 / \mathrm{HH}-23.601$.

26. Koster A, van Krieken JH, Mackenzie MA, Schraders M, Borm GF, van der Laak JA, et al. Increased vascularisation predicts favourable outcome in follicular lymphoma. Clin Cancer Res. 2005 Jan 1;11(1):154-61.

27. Farinha P, Kyle AH, Minchinton AI, Connors JM, Karsan A, Gascoyne RD. Vascularization predicts overall survival and risk of transformation in follicular lymphoma. Haematologica. 2010 Dec;95(12):2157-60. doi: 10.3324/haematol.2009.021766.

28. Vuković I, Brešković T, Duplančić D, Batinić T, Štula I, Bulat $\mathrm{C}$, et al. Castleman's disease presenting as a tumorous paracardiac formation. Acta Clin Croat. 2016 Mar;55(1):161-6. doi. org/10.20471/acc.2016.55.01.22.

29. Ganjo KN, An CS, Robertson MJ, Gordon LI, Sen JA, Weisenbach J, et al. Rituximab, bevacizumab and $\mathrm{CHOP}$ (RA-CHOP) in untreated diffuse large B-cell lymphoma: safety, biomarker and pharmacokinetic analysis. Leuk Lymphoma. 2006 Jun; 47(6). 998-1005. doi. 10.1080/10428190600563821.

30. Ruan J. Antiangiogenic therapies in non-Hodgkin's lymphoma. Curr Cancer Drug Targets. 2011 Nov;11(9):1030-43. doi: 10.2174/156800911798073014.

\title{
Sažetak \\ KLINIČKA VAŽNOST VEGF-A I MIKROŽILNE GUSTOĆE U DIFUZNOM LIMFOMU VELIKIH B-STANICA I FOLIKULARNOM LIMFOMU NISKOG STUPNJA
}

\author{
L. Shahini, S. Gašparov, G. Petruševska, S. Manxbuka Kerliu, F. Veselaj, F. Kurshumliui F. Kavaja
}

Angiogeneza je bitna za razvoj, rast i progresiju tumora. Iako je vaskularni endotelni faktor rasta (VEGF) dobro poznati proangiogeni čimbenik, njegov utjecaj na limform nije u potpunosti razjašnjen. Cilj ovoga istraživanja bio je procijeniti izraženost VEGF-A i mikrožilnu gustoću (MVD) kod agresivnog limfoma kao što je difuzni limfom velikih B-stanica (DLBCL), kod indolentnih limfoma kao što je folikularni limfom niskog stupnja (FL) i kod reaktivne folikularne hiperplazije limfnih čvorova (FH). Analiza CD31 provedena je u 80 prospektivnih i retrospektivnih slučajeva (30 DLBCL, $30 \mathrm{FL}$ i $20 \mathrm{FH}$ ) imunohistokemijskim bojenjem za procjenu gustoće krvnih žila, kao i ukupnog broja endotelnih stanica pozitivnih na CD31. Rezultati su uspoređeni s relevantnim kliničkim podacima. MVD je bila 85\% kod FH, 60\% kod DLBCL i 43\% kod FL niskog stupnja. VEGF-A je bio značajno viši u DLBCL u odnosu na FL niskog stupnja i FH. Statistički značajna udruženost MVD i VEGF-A s Internacionalnim prognostičkim indeksom (IPI) utvrđena je kod DLBCL. Visoka izraženost MVD i VEGF-A zabilježena je u bolesnika s DLBCL s visokim IPI, dok nije bilo statistički značajne udruženosti MVD i VEGF-A s Internacionalnim prognostičkim indeksom za folikularni limfom kod FL niskog stupnja. Rezultati ovog istraživanja ukazuju na važan odnos između angiogeneze i limfoma visokog stupnja.

Ključne riječi: Vaskularni endotel, faktor rasta A; Limfom, ne-Hodgkin; Limfom velikih B-stanica, difuzni; Limfom, folikularni; Limfni čvorovi; Hiperplazija 